\title{
Synthesis and Trypanocidal Activity of 7, 2'-Dioxygenated Isoflavones and Oxypropanolamine Derivatives
}

\author{
Terezinha de J. Faria ${ }^{*}, a$, Luiz G. Fonseca e Silva ${ }^{b}$,José D. de Souza Filho ${ }^{b}$, Egler Chiari ${ }^{c}$ \\ and Alaíde B. de Oliveira
}

${ }^{a}$ Departamento de Química, CCE, Universidade Estadual de Londrina, CP 6001, 86051-990, Londrina-PR, Brazil
${ }^{b}$ Departamento de Química, ICEx e ${ }^{d}$ Departamento de Produtos Farmacêuticos, Faculdade de Farmácia,
Universidade Federal de Minas Gerais, Av. Antônio Carlos, 6627, 31270-901, Belo Horizonte-MG, Brazil
${ }^{c}$ Departamento de Parasitologia, ICB, Universidade Federal de Minas Gerais, CP 2486, 31270-901,

Belo Horizonte-MG, Brazil

\begin{abstract}
7,2'-Di-hidroxiisoflavona apresentou atividade contra tripomastigotas sanguíneos do Trypanosoma cruzi, agente etiológico da doença de Chagas, o que motivou a síntese de derivados anfifílicos de potencial utilização como quimioprofilático para esterilização de sangue para transfusão. Esta substância foi obtida por desmetilação da 7-hidroxi-2'-metoxiisoflavona, sintetizada via desoxibenzoína, seguindo-se eterificação com epicloridrina e abertura do anel oxirânico com dietilamina para levar à 7-oxipropanolamina, a qual, por tratamento com iodeto de metila, forneceu o sal de amônio correspondente. Nos ensaios in vitro com tripomastigotas sanguíneos do $T$. cruzi, a 7-hidroxi-2'-metoxiisoflavona foi inativa e a 7-oxipropanolamina foi mais ativa do que a 7,2'-di-hidroxiisoflavona. Já o sal de amônio, não só não eliminou completamente o parasita do sangue como causou lise total dos eritrócitos. Portanto, o sal de amônio não é adequado para o uso como profilático na transmissão do T.cruzi por transfusão sangüínea. A atividade tripanossomicida da 7,2'-di-hidroxiisoflavona e do seu derivado 7oxipropanolamina estimulam a avaliação in vivo destas substâncias como potenciais quimioterápicos para tratamento da doença de Chagas, sendo necessários alguns gramas destas substâncias que poderão ser obtidos pelos processos simples descritos neste trabalho.
\end{abstract}

7, 2'-Dihydroxyisoflavone was shown to be active against the bloodstream trypomastigote form of Trypanosoma cruzi, the etiologic agent of Chagas' disease. Amphiphilic derivatives of this isoflavone were synthezised aiming to obtain hydrosoluble compounds of potential use as prophylactic agents to be added to blood for transfusion. This isoflavone was obtained by demethylation of 7-hydroxy2'-methoxyisoflavone that was synthesized via the intermediate deoxybenzoin. Its reaction with epichlorohydrin, followed by aminolysis with diethylamine, afforded the 7-oxypropanolamine which on treatment with methyl iodide gave the corresponding ammonium salt. The 7-hydroxy-2'methoxyisoflavone was inactive in the in vitro assays, the 7-oxypropanolamine was more active than 7, 2'-dihydroxyisoflavone while the ammonium salt has not eliminated the parasite from the blood besides causing total lysis of the erythrocytes. The simple synthetic procedures described in the present paper can be used to provide gram quantities of 7,2'-dihydroxyisoflavone and its $7-$ oxypropanolamine derivative that should be further investigated in in vivo murine models as potential chemotherapeutic agents for treatment of Chagas' disease.

Keywords: isoflavones, aryloxypropanolamines, trypanocidal activity, Trypanosoma cruzi

\section{Introduction}

Chagas' disease is a serious health problem in Central and South America. It has been estimated that 16-18 million

*e-mail: tjfaria@uel.br people are infected in Latin America and 100 million are exposed to the risk of infection. ${ }^{1,3}$ Despite the identification of the hemoflagellate protozoan Trypanosoma cruzi as the etiologic agent of this disease in 1909, only two drugs were marketed, in the period of 1975 to 1994, for the clinical treatment of the infection, nifurtimox (nitrofuran) and 
benznidazole (nitroimidazole) which are effective only in the acute phase and in recent chronic infection. Benznidazole is actually the only available drug since nifurtimox has had its commercialization discontinued. ${ }^{3}$ In Brazil, transmission of $T$. cruzi by insect vectors is under control and transmission by blood transfusion is now an important mechanism of infection. ${ }^{2}$ Gentian violet is recommended as prophylatic drug in blood banks of endemic areas, but there are some restrictions on its use. ${ }^{3}$

The lack of effective drugs for treatment of Chagas' disease and to prevent blood transmission creates a need to find new trypanocidal agents. ${ }^{4}$ Amphiphilic cationic drugs having a hydrophobic ring moiety and an ionizable amine group as, for example, mepacrine, isothipendyl and maprotiline showed in vitro activity against $T$. cruzi but no one could substitute gentian violet. ${ }^{5-7}$ Screening of plant extracts and natural products revealed several trypanocidal natural products including isoflavonoids..$^{4,8,10-12}$ However, the water insolubility of most of these compounds is a serious limitation to their use for sterilization of blood for transfusion. Considering previous results on the trypanocidal effect of isoflavonoids ${ }^{11}$ we decided to carry on the synthesis of 7,2'-dioxygenated isoflavones and oxypropanolamines derivatives for in vitro assays against bloodstream trypomastigotes of $T$. cruzi.

\section{Results and Discussion}

The oxypropanolamine $\mathbf{6}$ and its ammonium salt $\mathbf{7}$, an amphiphilic cationic derivative, were prepared as shown in Figure 1. The 7-hydroxy-2'-methoxyisoflavone (3) was synthesized by the Wähälä and Hase one-pot procedure that starts with appropriately substituted phenols and phenylacetic acids via intermediate deoxybenzoins (1,2diarylethanones). ${ }^{13}$ Previously, the cyclization of hydroxydeoxybenzoins to the corresponding isoflavones was carried on by reaction with boron trifluoride etherate and methanesulphonyl chloride in DMF. ${ }^{14}$ In the one-pot procedure for the synthesis of polyhydroxyisoflavones the intermediate deoxybenzoins are obtained by Friedel-Crafts reaction using boron trifluoride etherate as both catalyst and solvent, the cyclization occurring in situ by addition of DMF and mesyl chloride. ${ }^{13}$ The cyclization reaction of deoxybenzoin is also catalyzed by boron trifluoride, which is believed to form a complex with 2-hydroxyarylketones. The complexation deactivates the polyoxygenated aromatic ring preventing ring formylation and consequent polymerization while the methylene function is activated for formylation..$^{13}$ Therefore, the isoflavone 3 was prepared in good yield (83\%) from resorcinol (1) and 2'methoxyphenylacetic acid (2) (Figure 1). Demethylation of $\mathbf{3}$ with aluminium chloride ${ }^{15}$ gave the 7, 2'-dihydroxyisoflavone (4) (84\% yield). The oxypropanolamine 6, that would lead to the ammonium salt 7 , was synthesized by a reaction sequence that started with the preparation of the glycidic ether 5 ( $40 \%$ yield) from the corresponding phenoxide ion formed in situ, by treatment of 7,2'dihydroxyisoflavone (4) with $\mathrm{NaH}$ and subsequent reaction with epichlorohydrin. ${ }^{16}$ The selective etherification of the 7-hydroxyl group has occurred as expected since it is the most acidic in an isoflavone molecule due to the conjugation with the carbonyl group. ${ }^{15}$ Subsequently, the oxirane ring opening of $\mathbf{5}$ with diethylamine yielded, as expected, ${ }^{17}$ the aryloxypropanolamine 6 (51\% yield) that by reaction with methyl iodide, in acetone, gave the desired amphiphilic cationic derivative, the ammonium salt 7 (21\% yield).

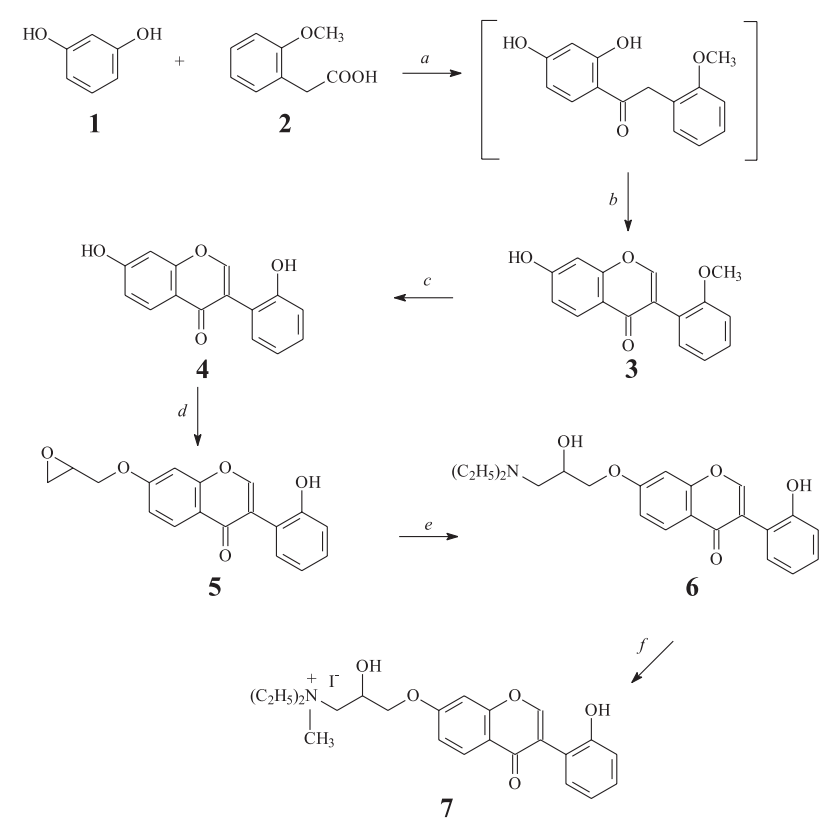

Figure 1. Synthesis of the quaternary ammonium salt 7. a) $\mathrm{BF}_{3} \cdot \mathrm{OEt}_{2} / 80$ ${ }^{\circ} \mathrm{C}, 2 \mathrm{~h}$; b) DMF/MsCl, $70{ }^{\circ} \mathrm{C}, 3 \mathrm{~h}$; c) $\mathrm{AlCl}_{3} / \mathrm{Nitrobenzeno,} 80^{\circ} \mathrm{C}, 2 \mathrm{~h}$; d) $\mathrm{DMF} / \mathrm{NaH}$, Epichlorohydrin, $\left.50^{\circ} \mathrm{C}, 16 \mathrm{~h} ; \mathrm{e}\right)\left(\mathrm{C}_{2} \mathrm{H}_{5}\right)_{2} \mathrm{~N}, \mathrm{MeOH}, 50^{\circ} \mathrm{C}, 3 \mathrm{~h}$; f) $\mathrm{CH}_{3} \mathrm{I}$, acetone, $60^{\circ} \mathrm{C}, 5 \mathrm{~h}$.

The isoflavones $\mathbf{3}$ and $\mathbf{4}$ are known compounds and were characterized by their melting points and spectroscopic data that are in agreement with those previously reported..$^{18}$ All the other substances obtained are novel chemical entities and have had their structures confirmed by IR, MS, ${ }^{1} \mathrm{H}$ and ${ }^{13} \mathrm{C}$ NMR spectral data. The assignments were based on 2D NMR experiments that were particularly useful for confirming the location of the glycidic ether chain of 5 at C-7 and not in C-2'. Two-dimensional nuclear Overhauser effect spectroscopy (NOESY) revealed the dipolar cross relation between both oxymethylenes protons ( $\mathrm{H}-1$ "a,b) of the 
side chain to the aromatic protons $\mathrm{H}-6$ and $\mathrm{H}-8$. Coincidentally, the signals of $\mathrm{H}-5$ ' and of $\mathrm{H}-3$ ' were overlapped with the ones of $\mathrm{H}-8$ and $\mathrm{H}-6$, respectively, but a correlation between $\mathrm{H}-5$, and hydrogens of the side chain would not be possible if it was located at C2 '. The n.O.e enhancement of signals of the hydrogens close to the oxymethylenes protons ( $\mathrm{H}-1$ " $\mathrm{a}, \mathrm{b}$ ), among others, were measured by NOEDIFF experiments and are shown in Table 1 . The decoupled ${ }^{13} \mathrm{C}$ NMR spectrum of compounds 5-7 presented characteristic signals for the carbons of the side chain that were assigned via DEPT and HMQC contour plot (Table 2). Different

Table 1. Quantitative Overhauser nuclear effect (\%) in the ${ }^{1} \mathrm{H}$ NMR spectrum of $\mathbf{5}$

\begin{tabular}{lcccccc}
\hline Irradiation $(\delta)$ & H-6 & H-8 & H-1”b & H-1”a & H-2” & H-3” \\
\hline H-1"a (4.04) & 3.04 & 6.64 & 14.15 & - & 1.36 & 2.68 \\
H-1"b (4.41) & 2.74 & 4.93 & - & 11.13 & 2.99 & - \\
\hline
\end{tabular}

Table 2. ${ }^{13} \mathrm{C}$ NMR data for the side chain of compounds 5, 6 and 7 (100 $\mathrm{MHz})$

\begin{tabular}{|c|c|c|c|}
\hline \multirow[b]{2}{*}{ Carbon } & \multicolumn{3}{|c|}{ Compound } \\
\hline & 5 & 6 & 7 \\
\hline 1 ' & 69.5 & 70.0 & 70.5 \\
\hline 2 , & 49.7 & 65.2 & 63.7 \\
\hline $3^{\prime}$ & 48.8 & 55.9 & 62.6 \\
\hline $\mathrm{CH}_{2}$ & - & 47.5 & $\begin{array}{l}58.5 \\
58.2\end{array}$ \\
\hline $\mathrm{CH}_{3}$ & - & 11.1 & $\begin{array}{l}8.1 \\
8.1\end{array}$ \\
\hline $\mathrm{NCH}_{3}$ & - & - & 48.9 \\
\hline
\end{tabular}

signals were observed for each methyl ( $\delta 8.1$ and 8.1) and methylene ( $\delta 58.5$ and 58.2) carbons of the two Nethyl groups, as expected for the ammonium salt $\mathbf{7}$. Moreover, the signals of the carbons linked to the nitrogen are downfield shifted compared to the corresponding carbons of $\mathbf{6}$ (Table 2).

All the synthesized compounds were evaluated for in vitro activity against the bloodstream trypomastigote form of T. cruzi. A compound was considered as active when it caused a complete elimination of parasites from blood and inactive when parasites were still observed at the microscope after $24 \mathrm{~h}$ at $4{ }^{\circ} \mathrm{C}$ (Table 3). All the compounds were assayed at three concentrations at which $\mathbf{3}, \mathbf{5}$ and $\mathbf{7}$ were inactive. The 7,2'-dihydroxyisoflavone (4) showed activity in the two higher concentrations while the 2'-O-methyl derivative (3) and the 7-O-glycidic ether 5 were inactive in all the assayed concentrations. The oxypropanolamine $\mathbf{6}$ was more active than the isoflavone 4. It was significantly effective in eliminating the parasite from blood up to the concentration of 1.13 $\mu \mathrm{mol} \mathrm{L}-1$ and was inactive at $0.56 \mu \mathrm{mol} \mathrm{L}^{-1}$ but it caused partial lysis of the erythrocytes even at the lowest assayed concentration. The higher activity of $\mathbf{6}$ in relation to $\mathbf{4}$ can be related to its more hydrophyllic character and possibly to the presence of its protonated form in the medium of the test. With the ammonium salt 7 a reduction in the number of $T$. cruzi trypomastigotes was observed and it caused a complete lysis of the erythrocytes. Therefore this compound is not useful as chemoprophylatic agent for preventing the transmission of $T$. cruzi by blood transfusion. On the other hand the effects of compounds $\mathbf{4}$ and $\mathbf{6}$ suggest further studies evaluating their potential use as chemotherapeutic agents in the treatment of Chagas' disease. The next step should be in vivo assays in mice experimentally infected with T. cruzi and will require gram quantities of these

Table 3. In vitro activities of compounds 3-7 against bloodstream trypomastigotes of Trypanosoma cruzi $\mathrm{Y}$ strain ${ }^{\mathrm{a}}$

\begin{tabular}{|c|c|c|c|c|}
\hline \multirow[b]{2}{*}{ Compounds } & \multicolumn{4}{|c|}{ Concentrations / $\left(\mu \mathrm{mol} \mathrm{L}{ }^{-1}\right)$} \\
\hline & 4.50 & 2.25 & 1.13 & 0.56 \\
\hline 3 & $\left(1206.00 \mu \mathrm{g} \mathrm{mL}^{-1}\right)$ & $\left(603.00 \mu \mathrm{g} \mathrm{mL}^{-1}\right)$ & $\left(301.50 \mu \mathrm{g} \mathrm{mL}^{-1}\right)$ & ND \\
\hline & + & + & + & \\
\hline 4 & $\left(1143.00 \mu \mathrm{g} \mathrm{mL}^{-1}\right)$ & $\left(571.50 \mu \mathrm{g} \mathrm{mL}^{-1}\right)$ & $\left(285.75 \mu \mathrm{g} \mathrm{mL}^{-1}\right)$ & ND \\
\hline & - & - & - & \\
\hline 5 & $\begin{array}{c}\left(1395.00 \mu \mathrm{g} \mathrm{mL}^{-1}\right) \\
+\end{array}$ & $\begin{array}{c}\left(697.50 \mu \mathrm{g} \mathrm{mL}^{-1}\right) \\
+\end{array}$ & $\begin{array}{c}\left(348.75 \mu \mathrm{g} \mathrm{mL}^{-1}\right) \\
+\end{array}$ & ND \\
\hline 6 & $\left(1723.50 \mu \mathrm{g} \mathrm{mL}^{-1}\right)$ & $\left(861.75 \mu \mathrm{g} \mathrm{mL}^{-1}\right)$ & $\left(430.88 \mu \mathrm{g} \mathrm{mL}^{-1}\right)$ & $\left(215.44 \mu \mathrm{g} \mathrm{mL}^{-1}\right)$ \\
\hline & $-(\mathrm{L})$ & $-(\mathrm{L})$ & $-(\mathrm{L})$ & $+(\mathrm{L})$ \\
\hline 7 & $\begin{array}{c}\left(2362.50 \mu \mathrm{g} \mathrm{mL}^{-1}\right) \\
+(\mathrm{TL})\end{array}$ & $\begin{array}{c}\left(1181.25 \mu \mathrm{g} \mathrm{mL}^{-1}\right) \\
+(\mathrm{TL})\end{array}$ & $\begin{array}{c}\left(590.62 \mu \mathrm{g} \mathrm{mL}^{-1}\right) \\
+(\mathrm{TL})\end{array}$ & ND \\
\hline
\end{tabular}

$\overline{{ }^{a}}$ positive control, gentian violet $\left(130 \mu \mathrm{g} \mathrm{mL}{ }^{-1}\right)$; negative controls, TCM199, TCM199 + DMSO; ${ }^{+}$inactive, presence of bloodstream trypomastigotes; - active, absence of bloodstream trypomastigotes; ${ }^{\mathrm{L}}$ partial lysis of erythrocytes; ${ }^{\mathrm{TL}}$ total lysis of erythrocytes; ${ }^{\mathrm{ND}}$ not determined. 
compounds that can be prepared by the simple procedures described in this paper.

\section{Experimental}

\section{Biossay}

Bloodstream trypomastigotes of $T$. cruzi $\mathrm{Y}$ strain were obtained from adult male albino mice acutely infected on day 7. Each compound (at two times the molecular mass/ 100) was dissolved in $200 \mu \mathrm{L}$ of dimethyl sulfoxide (DMSO) plus $2.0 \mathrm{~mL}$ of tissue culture medium 199 (TC199) containing 10\% heat-inactivated fetal bovine serum. Aliquots of each solution were mixed with equal volume of blood from acutely infected mice. Final working concentrations were $4.50 \mu \mathrm{mol} \mathrm{L}{ }^{-1}, 2.25 \mu \mathrm{mol} \mathrm{L}-1,1.13$ $\mu \mathrm{mol} \mathrm{L}-1$ and $0.56 \mu \mathrm{mol} \mathrm{L}-1$. A parasite density of $2 \times 10^{5}$ per $100 \mu \mathrm{L}$ of blood was calculated for each flat-bottom test tube, as described previously. ${ }^{11}$ Control tubes were included for TCM199, TCM199 plus DMSO and gentian violet $\left(130 \mu \mathrm{g} \mathrm{mL}^{-1}\right)$. The tubes were incubated at $4{ }^{\circ} \mathrm{C}$ for $24 \mathrm{~h}$. Thereafter, $5 \mu \mathrm{L}$ of each suspension was examined microscopically for the presence of motile parasites.

\section{Chemical synthesis}

Melting points are uncorrected. NMR spectra were obtained on a BRUKER AVANCE DRX400 spectrometer with TMS as internal standard. Infrared spectra were recorded on a Shimadzu IR 408 instrument (Departamento de Química, Universidade Federal de Minas Gerais). Mass spectra were determined on a VG Autospec instrument (LEMAR-LPN-PADETEC - Universidade Federal do Ceará). DMF was distilled from phosphorus pentoxide and stored in the presence of $3 \AA$ molecular sieves. $\mathrm{BF}_{3} \cdot \mathrm{OEt}_{2}$ was distilled from calcium hydride. Organic extracts were dried over anhydrous sodium sulfate. The starting compound 1 was obtained from Merck and $\mathbf{2}$ from Aldrich.

7-Hydroxy-2'-methoxyisoflavone [7-hydroxy-3-(2methoxyphenyl)-4H-1-benzopyran-4-one] (3). Prepared by the one-pot procedure for the synthesis of polyhydroxyisoflavones. ${ }^{13}$ A solution of resorcinol $(0.33 \mathrm{~g}, 3$ $\mathrm{mmol})$ and 2-methoxyphenylacetic acid $(0.50 \mathrm{mg}, 3$ $\mathrm{mmol})$ in freshly distilled $\mathrm{BF}_{3} \cdot \mathrm{Et}_{2} \mathrm{O}(7 \mathrm{~mL})$ was stirred and heated at $60-80{ }^{\circ} \mathrm{C}$ for $1.5 \mathrm{~h}$. For cyclization the reaction mixture was cooled to room temperature and dry DMF (3 $\mathrm{mL})$ was added. The mixture was again heated to $50{ }^{\circ} \mathrm{C}$ and a solution of methanesulphonyl chloride $(3.0 \mathrm{~mL})$ in dry DMF $(2.5 \mathrm{~mL})$ was added slowly. After $4.0 \mathrm{~h}$ at $80-100{ }^{\circ} \mathrm{C}$, the reaction mixture was cooled to room temperature and poured, without mechanical stirring, into a large volume of ice-cold aqueous sodium acetate $(12 \%, \mathrm{~m} / \mathrm{v})$. The crude product 3 was filtered off and recrystallized from ethanol $(0.65$ g, 83\%). White crystals, mp 230-234 ${ }^{\circ} \mathrm{C}$; lit. ${ }^{18} \mathrm{mp} 235$ $237{ }^{\circ} \mathrm{C} ;{ }^{1} \mathrm{H}$ NMR spectrum in accord with data reported in literature. ${ }^{18}$

7, 2'-Dihydroxyisoflavone [7-hydroxy-3-(2-hydroxyphenyl)-4H-1-benzopyran-4-one] (4). Prepared according to Aghoramurthy et al. ${ }^{15}$ from 7-hydroxy-2'-methoxyisoflavone (3) $(0.13 \mathrm{~g}, 0.5 \mathrm{mmol})$ by treatment with aluminum chloride $(0.17 \mathrm{~g}, 1.3 \mathrm{mmol})$ in nitrobenzene $\left(3.0 \mathrm{~mL}\right.$ ) at $80^{\circ} \mathrm{C}$ for $1.5 \mathrm{~h}$. Thereafter, the reaction mixture was added to ice conc. $\mathrm{HCl}(40 \mathrm{~mL})$ and extracted with dichloromethane $(5 \times 50 \mathrm{~mL})$. The organic layer was extracted with $5 \%$ aqueous $\mathrm{NaOH}(4 \times 20 \mathrm{~mL})$. The aqueous alkaline solution was acidified and product $\mathbf{4}$ was extracted with dichloromethane $(5 \times 80 \mathrm{~mL})(0.11 \mathrm{~g}, 84 \%)$. White crystals; mp 207-208 ${ }^{\circ} \mathrm{C}$; lit. ${ }^{18} \mathrm{mp} 209-211{ }^{\circ} \mathrm{C} ;{ }^{1} \mathrm{H}$ NMR spectrum in accord with literature data. ${ }^{18}$

1,2-Epoxy-3-[3-(2-hydroxyphenyl-4-H-1-benzopyranoxy-4-one Jpropane (5). To a solution of isoflavone 4 (1.22 g, $5 \mathrm{mmol})$ in DMF (10 mL), kept in an ice-water bath, a suspension of $\mathrm{NaH}(0.90 \mathrm{~g}, 7.5 \mathrm{mmol}, 60 \%$ in mineral oil) in DMF $(10 \mathrm{~mL})$ was added and the mixture was then stirred for $15 \mathrm{~min}$, at $5{ }^{\circ} \mathrm{C}$. Epichlorydrin $(2$ $\mathrm{mL}, 25 \mathrm{mmol}$ ) was added and the mixture was stirred at $50{ }^{\circ} \mathrm{C}$, for $16 \mathrm{~h}$. The reaction mixture was poured into a saturated aqueous $\mathrm{NaCl}$ solution and extracted with dichloromethane. The combined organic extracts were dried over $\mathrm{Na}_{2} \mathrm{SO}_{4}$, and the solvent was evaporated. The residue was chromatographed on a silica gel column using a mixture of hexane and dichloromethane (1:1) as eluant to give the glycidic ether $5(0.62 \mathrm{~g}, 40 \%)$. Pale yellow crystals, mp $127-128{ }^{\circ} \mathrm{C}$. IR (KBr) $v_{\max } / \mathrm{cm}^{-1}: 3000$, 1620, 1565, 1490, 1450, 1390, 1345, 1275, 1240, 1210, $1100,1055,1035,1015,910,830,755 ;{ }^{1} \mathrm{HNMR}\left(\mathrm{CDCl}_{3}\right)$ $\delta 8.93$ (s, 1H, 2'-OH), 8.27 (d, 1H, J $8.9 \mathrm{~Hz}, 5-\mathrm{H}), 8.09$ (s, 1H, 2-H), 7.35 (ddd, 1H, J 1.7, 7.3, 7.7 Hz, 4'-H), 7.17 (dd, 1H, J 1.7, 7.7 Hz, 6'-H), 7.11 (dd, 1H, J 2.4, $8.9 \mathrm{~Hz}, 6-\mathrm{H}), 7.10$ (dd, 1H, J 1.2, 8.1Hz, 3'-H), 6.996.95 (m, 2H, 5'-H, 8-H), 4.41 (dd, 1H, J 2.8, $11.1 \mathrm{~Hz}$, H-1"a or H-1"b), 4.04 (dd, 1H, J 6.0, $11.1 \mathrm{~Hz}, \mathrm{H}-1$ "'a or H-1"b ${ }_{\mathrm{b}}$ ), 3.44-3.40 (m, 1H, H-2"), 2.97 (t, 1H, J 4.8, H-3"a), 2.81 (dd, 1H, J 2.6, 4.8 Hz, H-3”b); m/z 310.051 $\left(\mathrm{M}^{+}, 100 \%\right), 293.057$ (17), 237.052 (16), 193.060 (11), 145.032 (23), 118.044 (29), 89.047 (13).

N, N-Diethyl-2-hydroxy-3-[3-(2-hydroxyphenyl-4-H-1benzopyranoxy-4-one)]-1-propylamine (6). A solution 
of $5(0.47 \mathrm{~g}, 1.5 \mathrm{mmol})$ and diethylamine $(2.5 \mathrm{~mL})$ in methanol $(25 \mathrm{~mL})$ was stirred at $50{ }^{\circ} \mathrm{C}$, for $3 \mathrm{~h}$. The solvent was evaporated and the residue was chromatographed on a silica gel column using a mixture of dichloromethane and methanol (9.5:0.5) as eluant to give compound $6(0.29 \mathrm{~g}$, $51 \%)$ as an oil. IR (KBr) $v_{\text {max }} / \mathrm{cm}^{-1}: 2900,1620,1445,1385$, 1250, 1200, 1090, 1030, 830, 750; ${ }^{1} \mathrm{HNMR}\left(\mathrm{CDCl}_{3}\right) \delta 8.27$ (d, $1 \mathrm{H}, J 8.9 \mathrm{~Hz}, 5-\mathrm{H}), 8.10(\mathrm{~s}, 1 \mathrm{H}, 2-\mathrm{H}), 7.37-7.33(\mathrm{~m}, 1 \mathrm{H}$, 4'-H), 7.18 (dd, 1H, J 1.6, 7.7, 6'-H), 7.12-7.09 (m, 2H, 3'H, 6-H), 7.00-6.96 (m, 2H, 5'-H, 8-H), 4.22-4.18 (m, 1H, H-2"), 4.15 (dd, 1H, J 5.0, 9.5 Hz, H-1"a or H-1"b), 4.10 (dd, 1H, J 5.0, $9.5 \mathrm{~Hz}, \mathrm{H}-1$ "a or H-1"b), 2.88-2.62 (m, 6H,

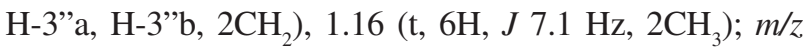
$383.227\left(\mathrm{M}^{+}, 6 \%\right), 366.163$ (15), 312.133 (10), 270.114 (45), 254.046 (25), 227.059 (22), 197.053 (11), 181.061 (8), 137.019 (21), 116.103 (49), 86.101 (100).

N,N-Diethyl-N-methyl-2-hydroxy-3-[3-(2-hydroxyphenyl4-H-1-benzopyranoxy-4-one)]-1-propyl ammonium iodide (7). To a solution of $6(0.20 \mathrm{mg}, 0.56 \mathrm{mmol})$, in dry acetone $(5 \mathrm{~mL})$, methyl iodide was added. The reaction mixture was stirred at $60{ }^{\circ} \mathrm{C}$, for $5 \mathrm{~h}$, filtered off, and the solvent was evaporated. The crude salt was chromatographed on a silica gel column using a mixture of dichloromethane and methanol (9.5:0.5) as eluant. The residue obtained was purified by precipitation from its solution in methanol by the addition of diethyl ether to give the ammonium salt $7(0.62 \mathrm{~g}, 21 \%)$. White powder, mp $145-147{ }^{\circ} \mathrm{C}$. IR $(\mathrm{KBr}) v_{\max } / \mathrm{cm}^{-1}: 3200,1620,1570,1490,1450,1380$, 1175, 1240, 1205, 1100, 1040, 895, 830, 790, 770; ${ }^{1} \mathrm{HNMR}$ $\left(\mathrm{DMSO}_{6}\right.$ ) $\delta 9.19$ (s, 1H, 2'-OH), 8.24 (d, 1H, J $9.0 \mathrm{~Hz}$, 5-H), 8.10 (s, 1H, 2-H), 7.02-6.98 (m, 3H, 4'-H, 6'-H, 8-H), 6.91 (dd, 1H, J 2.4, 9.0 Hz, 6-H), 6.69 (d, 1H, J 7.6 Hz, 3'-H), 6.64 (ddd, 1H, J 1.0, 7.0, 7.5 Hz, 5'-H), 4.274.24 (m, 1H, H-2"), 3.95 (dd, 1H, J 5.0, $10.1 \mathrm{~Hz}, \mathrm{H}-1$ "a or H-1"b), 3.90 (dd, 1H, J 5.5, $10.1 \mathrm{~Hz}, \mathrm{H}-1$ "a or H-1"b), 3.27-3.17 (m, 6H, H-3"a, H-3"b, 2 $\mathrm{CH}_{2}$ ), 2.84 (s, 3H, $\mathrm{CH}_{3}$ ), $1.06\left(\mathrm{t}, 6 \mathrm{H}, J 7.0 \mathrm{~Hz}, 2 \mathrm{CH}_{3}\right) ; \mathrm{m} / z 439.000\left(\mathrm{M}^{+}, 4 \%\right)$, 438.173 (11), 366.171 (6), 310.101 (23), 254.074 (47), 197.067 (5), 141.941 (10), 86.111 (100).

\section{Acknowledgments}

The authors thank to CNPq and CAPES for fellowships to $\mathrm{ABO}(\mathrm{CNPq}$, IA Researcher) and TJF (CAPES, Doctorate).

\section{References}

1. Schofiel, C. J.; Maudlin, I.; Int. J. Parasit. 2001, 31, 615.

2. Wendel S.; Dias, J.C.P. In Chagas' Disease (American trypanosomiasis): Its Impact on Transfusion and Clinical Medicine; Wendel, S.; Brener, Z.; Camargo, M. E.; Rassi, A., eds.; ISBT Brazil'92-SBHH: São Paulo, 1992, p 165.

3. Coura, J. R.; De Castro, S. L.; Mem. Inst. Oswaldo Cruz 2002, 97, 3.

4. Fournet, A.; Arias, A. R.; Ferreira, M. E.; Nakayama, H.; Ortiz, S.T.; Schinini, A.; Samudio, M.; Bilbao, N. V.; Lavaut, M.; Bonté, F.; Int. J. Antimicrob. Agents 2000, 13, 189.

5. Cover, B.; Gutteridge, W. E.; Trans. Roy. Soc. Trop. Med. Hyg. 1982, 76, 633.

6. Hammond, D. J.; Cover, B.; Gutteridge, W. E.; Trans. Roy. Soc. Trop. Med. Hyg. 1984, 78, 91.

7. Hammond, D. J.; Croft, S. L.; Hogg, J.; Gutteridge, W. E.; Acta Trop. 1986, 43, 367.

8. Sepúlveda-Boza, S.; Cassels, B. K.; Planta Med. 1995, 62, 98.

9. Bonnet, B.; Soullez, D.; Gorault. S.; Maes, L.; Landry, V.; Davioud-Charvet, E.; Segheraet, C.; Bioorg. Med. Chem. 2000, $8,95$.

10. Du, X.; Hansell, E.; Engel, J. C.; Caffrey, C. R.; Cohen, F. E.; McKerrow, J. H.; Chem. Biol. 2000, 7, 733.

11. Chiari, E.; Oliveira, A. B. de; Raslan, D. S.; Mesquita, A. A. L.; Tavares, K. G.; Trans. Roy. Soc. Trop. Med. Hyg. 1991, 85, 372.

12. Pinto, A. V.; Ferreira, V. F.; Capella, R. S.; Gilbert, B.; Pinto, M. C. R.; Da Silva, J. S.; Trans. Roy. Soc. Trop. Med. Hyg. 1987, 81, 609.

13. Wähälä, K.; Hase, T. A.; J. Chem. Soc., Perkin Trans 1. 1991, 3005.

14. Bass, R. J.; J. Chem. Soc., Chem. Commun. 1976, 78.

15. Aghoramurthy, K.; Kukla, A. S.; Seshadri, T. R.; J. Indian Chem. Soc. 1961, 38, 1991.

16. Cox, M. T.; Jaggers, S. E.; Jones, G.; J. Med. Chem. 1978, 21, 182.

17. Kirk, D. N.; Chem. Ind. 1973, 109.

18. Bannwart, C.; Adlercreutz, H.; Wähälä, K.; Kotiaho, T.; Hesso, A.; Brunow, G.; Hase, T.; Biomed. Environ. Mass Spectrom. 1988, $17,1$. 